\title{
Follicular dynamics and temporal relationships among body temperature, oestrus, the surge of luteinizing hormone and ovulation in Holstein heifers treated with norgestomet
}

\author{
R. Rajamahendran and C. Taylor
}

Department of Animal Science, University British Columbia, Vancouver, British Columbia, Canada V6T 2 A2

\begin{abstract}
Summary. The effects of chronic treatment with norgestomet on follicular dynamics, corpus luteum growth and function as well as the temporal relationships among body temperature, oestrous behaviour, the luteinizing hormone ( $\mathrm{LH}$ ) surge and ovulation following implant removal were studied in 16 Holstein heifers. Oestrous cycles of the heifers were initially synchronized using 2 injections of prostaglandin F-2 $\alpha$ (PGF-2 $\alpha$ ) 12 days apart. The heifers were then implanted with a norgestomet ear implant for 9 days, beginning either at the middle of the synchronized cycle (dioestrus) or at the end of the synchronized cycle (pro-oestrus). Follicular dynamics, corpus luteum growth and regression, and plasma progesterone were not affected by norgestomet treatment at dioestrus. The dominant follicle present at the time of norgestomet implantation in the pro-oestrus group was maintained during the 9-day implant period in 6 of 8 heifers and ovulated after implant removal. Time from implant removal to onset of standing oestrus and time to LH peak following implant removal were highly correlated with the time of ovulation ( $r=0.92$ and 0.96 , respectively). Onset of standing oestrus and the LH peak and the onset of standing oestrus and peak vaginal and rectal temperatures were also highly correlated ( $r=0 \cdot 96,0.82$ and $0 \cdot 81$, respectively). It is concluded that any decrease in pregnancy rates following treatment with norgestomet is not due to asynchrony among oestrus, the LH surge and ovulation.
\end{abstract}

Kelwords: follicular dynamics; corpus luteum; oestrus; LH; ovulation; norgestomet; cow

\section{Introduction}

Failure to synchronize ( $100 \%)$ oestrus adequately and completely in cattle is a major limitation in successfully using artificial insemination. Various procedures to control oestrus and ovulation are being developed to overcome these limitations. Wiltbank \& Gonzalez Padilla (1975), Short et al. (1976) and Humphrey et al. (1977) used a synthetic progestin (norgestomet) in combination with oestradiol valerate to control oestrous cycles. This treatment is now commercially available as Synchro-Mate B (Ceva Labs, Kansas, USA) for synchronization of oestrus in dairy and beef heifers and post-partum beef cows. The incidence and synchrony of oestrus following the above treatment is high (Miksch et al., 1978; Spitzer et al., 1978), but numerous studies have reported lowered pregnancy rates (Rentfrow et al., 1987; Brown et al., 1988; Mikeska \& Williams, 1988).

It has been suggested that lowered pregnancy rates following norgestomet treatment may be due to (a) asynchrony between oestrus, the preovulatory surge of luteinizing hormone (LH) and ovulation (Rentflow et al., 1987); (b) a delay in the selection of the ovulatory follicle (Mikeska \& Williams, 1988); and (c) the stage of oestrous cycle at which norgestomet treatment was initiated 
(Brink \& Kiracofe, 1988). In an attempt to resolve these issues, the present study investigated (a) follicular dynamics and corpus luteum (CL) size and function before, during and after norgestomet treatment and (b) temporal relationships among changes in body temperature, the onset of standing oestrus, the LH surge and ovulation following norgestomet removal.

\section{Materials and Methods}

Animals and treatment. Sixteen Holstein heifers were selected at random from the University of British Columbia dairy herd for this study. Heifers were palpated per rectum to ensure normal ovarian and reproductive tract status and 2 injections of PGF-2a ( $30 \mathrm{mg}$ Lutalyse; Upjohn, Kalamazoo, MI, USA) were administered 12 days apart to synchronize oestrus. At oestrus, the heifers were allocated at random to 1 of 2 treatment groups. Heifers in Treatment 1 received a 6-mg norgestomet ear implant (Sanofi Canada Inc., Victoriaville, Quebec, Canada) between Days 9 and 11 (Day $0=$ day of synchronized oestrus) and heifers in Treatment 2 received the implant between Day 18 and 20 . The implant was left in place for 9 days and all heifers received $30 \mathrm{mg}$ of PGF- $2 \alpha 1$ day before implant removal.

Blood sampling, temperature measurement and oestrus detection. Blood samples were obtained by jugular venepuncture daily from the first day following oestrus resulting from the second injection of PGF-2 $\alpha$ until implant removal and every $4 \mathrm{~h}$ thereafter until the subsequent ovulation. The samples were collected into heparinized tubes, placed in ice immediately and centrifuged at $315 \mathrm{~g}$ for $20 \mathrm{~min}$ within $30 \mathrm{~min}$ of collection. Plasma was sampled and stored at $-20^{\circ} \mathrm{C}$ until analysis for progesterone and $\mathrm{LH}$. Rectal and vaginal temperatures were measured using a clinical thermometer every $4 \mathrm{~h}$ from implant removal until ovulation. Heifers were observed for signs of oestrus daily during norgestomet treatment and during the blood sampling times following implant removal. Onset of standing oestrus was defined as the time from implant removal until the first observation of a heifer standing to be mounted.

Ultrasound observation of the ovaries. The ovaries were scanned daily using a real-time linear array ultrasound scanner (Tokyo Keiki Co. Ltd. Tokyo, Japan) and a 5-MHz rectal transducer during the period of daily blood sampling until the onset of standing oestrus after implant removal and then every $2 \mathrm{~h}$ until ovulation which was determined by the acute disappearance of the dominant follicle (Rajamahendran et al., 1989; Rajamahendran \& Taylor, 1990). The ovaries were scanned in several planes to identify all visible follicles and the CL. Landmarks such as a $C L$, other follicles, the poles of the ovary and the orientation of the ovary were used to identify individual follicles. Appropriate images were arrested and structures measured using a built-in caliper system and permanent records were made using a video processing unit (Mitsubishi Electronics Co. Ltd, Tokyo, Japan).

Breeding and pregnancy diagnosis. Heifers were inseminated using previously frozen semen from the same bull $\sim 12 \mathrm{~h}$ after the onset of standing oestrus. Heifers not returning to oestrus within 28 days after insemination were scanned using ultrasound for confirmation of pregnancy (Taylor \& Rajamahendran, 1989). Pregnancy was diagnosed on the basis of visualization of a foetus with an identifiable heart beat.

Hormone analysis. Concentrations of progesterone and LH in plasma were determined using radioimmunoassay procedures described by Rajamahendran \& Taylor (1990) and Vorstermans \& Walton (1985). For LH, the assay standard was NIAMMD-bLH-4 $(2 \cdot 2 \times$ NIH-LH-Bl $)$. All results were then corrected to NIH-LH-BI. The sensitivities of the progesterone and LH assays were $0.05 \mathrm{ng} / \mathrm{ml}$ and $0.16 \mathrm{ng} / \mathrm{ml}$, respectively. Intra- and inter-assay coefficients of variation were, respectively, 9 and $12 \%$ for progesterone and 6 and $19 \%$ for LH. All the samples from each animal were processed within a single assay and only duplicates within $10 \%$ of each other were accepted.

Statistical analysis. Correlations among the onset of standing oestrus, peak vaginal and rectal temperatures, peak LH and ovulation were made using Pearson $r$ correlations. Comparisons between the 2 treatment groups were made using Student's $t$ test. Heifers receiving the implant during pro-oestrus served as controls for the heifers receiving the implant during dioestrus with regard to growth and atresia of dominant follicles and the onset of CL regression.

\section{Results}

Patterns of follicular dynamics for individual representative animals treated with norgestomet at dioestrus and pro-estrus are shown in Figs la and b, respectively. Fourteen of the 16 cycles, 7 from each treatment group, had 3 waves of follicular growth and the remaining two had 2 waves. A wave was characterized by the appearance of a pool of follicles and the emergence and differential growth of a single dominant follicle while the remainder of its cohorts regressed. The maximum diameter of the first $(16.7 \pm 1.8 \mathrm{vs} .17 \cdot 1 \pm 1 \cdot 1 \mathrm{~mm})$, second $(16.2 \pm 1.2 \mathrm{vs} .16 .0 \pm 1.1 \mathrm{~mm})$ and third $(19.3 \pm 1.7$ vs. $20.5 \pm 2.5 \mathrm{~mm})$ dominant follicles as well as the timing of regression of the first ( $14.2 \pm 0.8$ vs. $13.5 \pm 1.0$ days) and second ( $18.3 \pm 0.8$ vs. $17.5 \pm 0.7$ days $)$ dominant follicles 
did not differ between heifers treated with norgestomet at dioestrus and pro-oestrus. The maximum diameter of $\mathrm{CL}(31.2 \pm 2.1$ vs. $32.0 \pm 1.8 \mathrm{~mm})$, the maximum progesterone concentration $(4.3 \pm 0.3$ vs. $4.5 \pm 0.3 \mathrm{ng} / \mathrm{ml})$ and the timing of $\mathrm{CL}$ regression based on diameter $(18.6 \pm 1 \cdot 1$ vs. $18.3 \pm 1.7$ days) and progesterone concentration $(17.7 \pm 0.8$ vs. $17.5 \pm 1.0$ days $)$ were not different between heifers treated at dioestrus and pro-oestrus (Fig. 2).

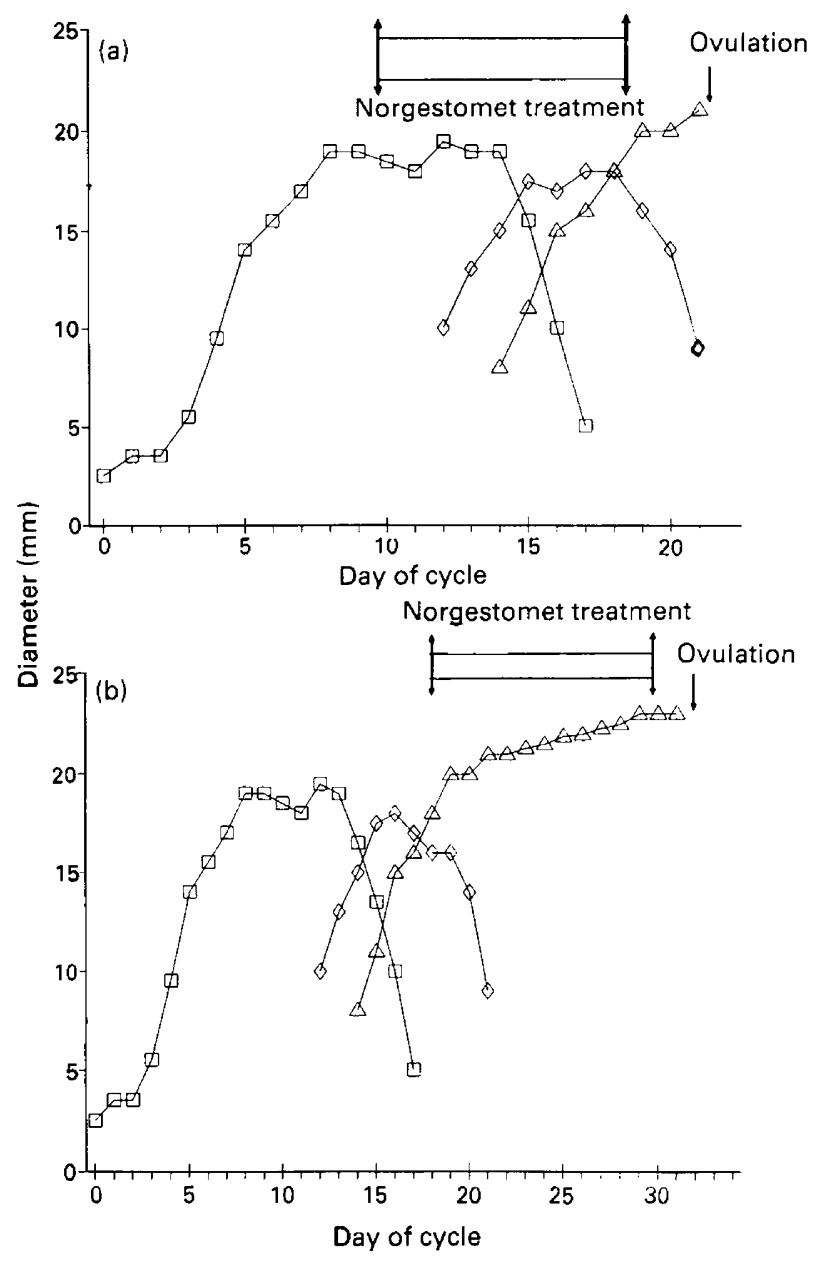

Fig. 1. Growth and regression pattern of $(\square)$ 1st, $(\diamond)$ 2nd and $(\triangle)$ 3rd dominant follicles in heifers treated with norgestomet during dioestrus (a) and pro-oestrus (b) (Day $0=$ day of oestrus following second prostaglandin F-2 $\alpha$ injection).

The dominant follicle present at implant removal went on to ovulate in all heifers treated with norgestomet at dioestrus. In heifers receiving norgestomet implants during pro-oestrus, $\mathrm{CL}$ regression was well underway at the time of implant insertion according to both the ultrasound images and progesterone data. The dominant follicle present at the time of implant insertion ovulated within $48 \mathrm{~h}$ in 2 out of 8 heifers. In the remaining 6 heifers, the dominant follicle was maintained for the entire 9-day period and went on to ovulate following implant removal. Two heifers that ovulated following implant insertion had small CL $(20 \mathrm{~mm}$ vs. $30 \mathrm{~mm}$ observed in heifers treated at dioestrus) at implant removal.

All heifers receiving the norgestomet implant during dioestrus were observed in standing oestrus within $54 \mathrm{~h}$ of norgestomet implant removal. All but one heifer of the 6 that received the 


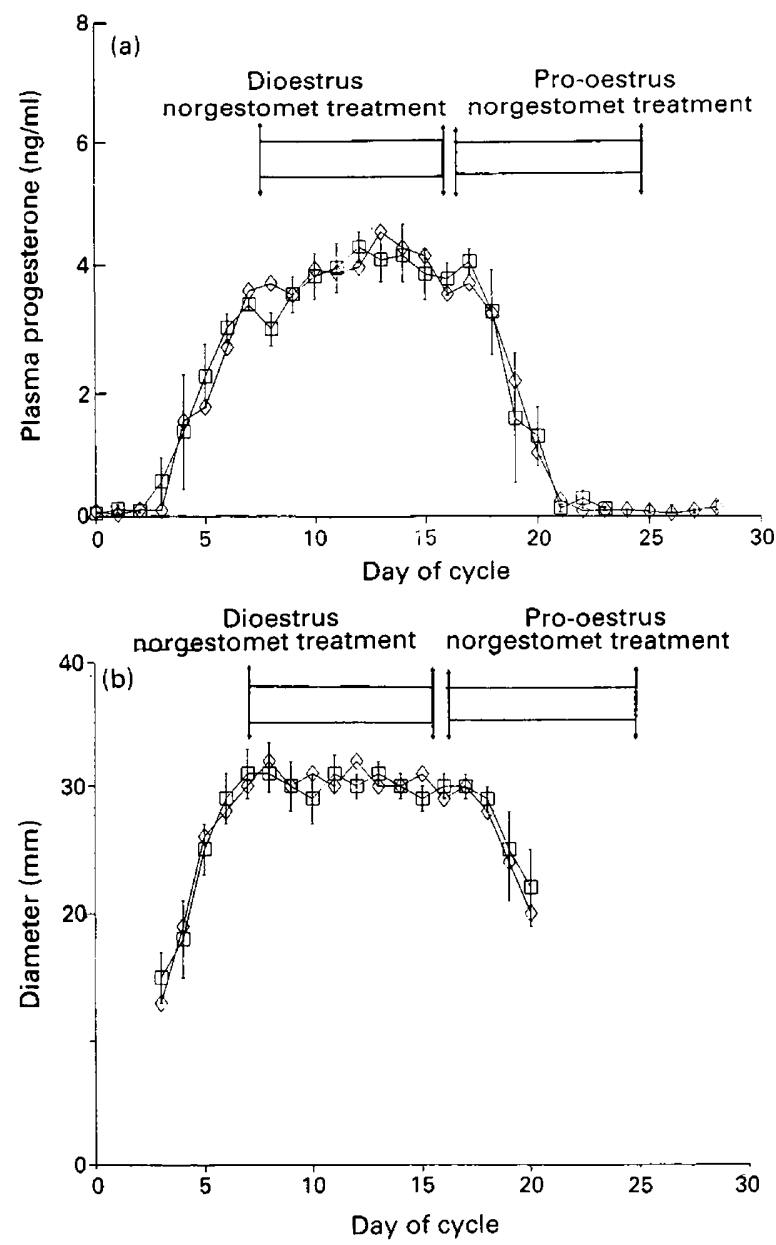

Fig. 2. (a) Mean ( \pm s.d.) plasma progesterone concentrations and (b) corpus luteum diameter in heifers treated with norgestomet at dioestrus $(\square)$ and pro-oestrus $(\diamond)$.

implant during pro-oestrus and maintained an ovulatory follicle were also observed in standing oestrus within $54 \mathrm{~h}$ of implant removal. Heifers that received the implant during pro-oestrus tended to come into standing oestrus sooner and ovulate earlier than heifers receiving the implant during dioestrus, although there was no significant difference $(P>0.05)$. Hence, data were combined to determine partial correlations. The onset of standing oestrus and LH peak were highly correlated $(P<0.01)$ with time of ovulation $(0.92$ and 0.96 , respectively; Table 1$)$. Standing oestrus and the LH peak and standing oestrus and peak vaginal and rectal temperatures were highly correlated $(0 \cdot 96,0 \cdot 82$ and $0 \cdot 81$, respectively).

Five animals in the dioestrus treatment group and 4 animals in the pro-oestrus group were diagnosed pregnant at 28 days after mating. The overall pregnancy rate was $60 \%$.

\section{Discussion}

Data in the present study do not support the suggestion that there is asynchrony between oestrus, the LH surge and ovulation in cows synchronized with norgestomet (Rentfrow et al., 1987). The correlations among the onset of standing oestrus and the LH surge, onset of standing oestrus and 
Table 1. Mean interval ( $\mathrm{h} \pm \mathrm{s.d}$.) from norgestomet implant removal to standing oestrus, temperature peaks, LH peak and ovulation, and correlation coefficients $(r)$ with the time to ovulation in cycling

Holstein heifers $(n=16)$

\begin{tabular}{lccc}
\hline Parameter & Mean & \pm s.d. & $r$ \\
\hline Standing oestrus & 30.7 & 9.8 & $0.92^{*}$ \\
Vaginal temperature & & & \\
$\quad$ peak & 36.4 & 9.9 & 0.51 \\
Rectal temperature & & & \\
$\quad$ peak & 36.8 & 8.6 & 0.44 \\
LH peak & 34.2 & 8.8 & $0.96^{*}$ \\
Ovulation & 60.1 & 11.4 & 1.00 \\
\hline
\end{tabular}

*Significantly correlated $(P<0.01)$.

ovulation, and the LH surge and ovulation were very strong. Although both rectal and vaginal peak temperatures were correlated with onset of standing oestrus, there was no correlation with ovulation. The single best practical parameter for basing the time of insemination was the onset of standing oestrus. The temporal relationships among standing oestrus, the LH surge and ovulation are in agreement with those reported in cows synchronized with double injections of PGF-2 $\alpha$ (Rajamahendran et al., 1989). The present study further supports the notion that young animals ovulate later in relation to oestrus and the LH surge than mature cows (Christenson et al., 1975; Schams et al., 1977; Rajamahendran et al., 1989).

Ultrasound imaging has been used effectively to monitor ovarian follicular dynamics and CL growth during different reproductive states in cattle and the measurement of these structures with a built-in caliper system has been validated (Pierson \& Ginther, 1988; Rajamahendran \& Walton, 1988). A wave-like pattern of follicular growth occurs during the oestrous cycle, 3 waves being common in heifers (Savio et al., 1988; Sirois \& Fortune, 1988). Three waves of follicular growth observed in heifers in the present study as well as the sizes of the dominant follicles, CL, timing of regression of dominant follicles and $C L$ are in agreement with the above reports.

The present study reveals that treatment of heifers with norgestomet at dioestrus (in the presence of CL) did not have any effect on the wave-like pattern of follicular growth, but, when the treatment was given at pro-oestrus (in the absence of $\mathrm{CL}$ ), the dominant follicle present was maintained for the duration of the treatment and there was no growth of medium or small follicles. These differences in follicular dynamics could be due to changes in the secretory pattern of $\mathrm{LH}$. Sirois et al. (1989) also reported prolonged maintenance of an ovulatory dominant follicle with the administration of low concentrations of progesterone. This implies that the norgestomet treatment given during pro-oestrus mimics the actions of low concentrations of progesterone. In cattle, administration of subnormal concentrations of progesterone has been shown to alter LH secretory pattern compared with animals receiving normal luteal concentrations (Ireland \& Roche, 1982; Roberson et al., 1989). Roberson et al. (1989) also reported that the concentrations of oestradiol$17 \beta$ were higher and the onset of preovulatory surge was earlier in cows receiving subnormal progesterone stimulation. This, according to our observation, may be related to the presence of an ovulatory follicle at progesterone withdrawal.

Two out of 8 heifers treated at pro-oestrus ovulated in spite of norgestomet treatment. This may be due to either insertion of the implant after the LH surge or insufficient norgestomet released from the implant to inhibit the LH surge. The fact that these 2 heifers had small CL at implant removal indicates that sufficient norgestomet was released to either suppress luteotrophic support (Ottobre, 1980; Battista et al., 1984) or cause early luteal regression (Ottobre, 1980, Garrett et al., 1988). Administration of progesterone early in the cycle has been shown to reduce oestrous cycle length in cattle (Rajamahendran et al., 1981). Possible reasons for reduced fertility in cows 
synchronized with norgestomet may lie in the altered dynamics of cows synchronized with the Syncro-Mate B method. Mikeska \& Williams (1988) suggested that retarded selection or maturation of the ovulatory follicle following norgestomet treatment may decrease conception rates in fixed-time-inseminated females. The present study clearly shows that the ovulatory follicle is maintained for the duration of treatment when they are treated at pro-oestrus. With luteolysis occurring early after norgestomet implantation, as a result of the oestradiol valerate injection in the SyncroMate B protocol, the ovulatory follicle would be selected and maintained for the remainder of the norgestomet treatment period in most of the treated animals. Administration of oestradiol valerate during the late luteal phase will disturb ovarian follicle growth and result in maintained follicles (Rajamahendran \& Walton, 1990). Although it appears that some follicles under norgestomet treatment ovulate at a later stage than dominant follicles from most normal cycling 3-wave heifers, the pregnancy rate in the present study does not suggest that prolonged maintenance of the dominant follicle is necessarily detrimental to conception rates.

In conclusion, it would appear that norgestomet treatment is an effective method of oestrus synchronization with no effect on the relationship among the onset of standing oestrus, the $\mathrm{LH}$ surge and ovulation following implant removal. Pregnancy rate in the present study does not reflect any decrease in fertility in heifers where the ovulatory follicle had been maintained for the 9-day norgestomet treatment. There may be a uterine effect, or other factors that have not been addressed in this study could be attributed to detrimental effects of norgestomet on pregnancy rates.

We thank Dr J. S. Walton of University of Guelph, Guelph, Ontario, Canada for his help in LH analysis and in the revision of the manuscript.

\section{References}

Battista, P.J., Rexford, C.E. \& Williams, W.F. (1984) Effects of progesterone administered to dairy heifers on sensitivity of corpora lutea to PGF and on plasma LH concentration. Theriogenology' 22, 47-58.

Brink, J.T. \& Kiracofe, G.H. (1988) Effects of estrous cycle stage at Syncro-Mate B treatment on conception and time to estrus in cattle. Theriogenology 29, 513. 518

Brown, L.N., Odde, K.G., King, M.E., LeFever, D.G. \& Neubauer, C.J. (1988) Comparison of MGA-PGF to Syncro-Mate $B$ estrous synchronization in beef heifers. Theriogenology 30, 1-12.

Christenson, R.K., Echterncamp, S.E. \& Laster, D.B. (1975) Oestrus, LH, ovulation and fertility in beef heifers. J. Reprod. Fert. 43, 543-546.

Garrett, J.E., Geisert, R.D., Zary, M.T., Gries, L.K., Wettemann, R.P. \& Buchanan, D.S. (1984) Effect of exogenous progesterone on prostaglandin $F_{2 a}$ release and the interestrous interval in the bovine. Proslaglandins 36, 85-96.

Humphrey, N.D., Hopper, L.D., Clemente, P., Dunn, T.G. \& Kaltenbach, C.C. (1977) Estrus and conception in heifers treated with norgestomet and estradiol valerate vs. norgestomet alone. J. Anim. Sci. (Suppl. 1) 45, 357.

Ireland, J.J. \& Roche, J. F. (1982) Effects of progesterone on basal LH and episodic $\mathrm{LH}$ and FSH secretion in heifers. J. Reprod. Fert. 64, 295-302.

Mikeska, J.C. \& Williams, G.L. (1988) Timing of preovulatory endocrine events, estrus, and ovulation in Brahman $\times$ Hereford females sychronized with norgestomet and estradiol valerate. J. Anim. Sci. 66, 939-946.
Miksch, E.D., LeFever, D.G., Mukembo, G., Spitzer, J.C. \& Wiltbank, J.N. (1978) Synchronization of estrus in beef cattie. II. Effect of an injection of norgestomet and an estrogen in conjunction with a norgestomet implant in heifers and cows. Theriogenology 10, 201-221.

Ottobre, J.S., Lewis, G.S., Thayne, W.V. \& Inskeep, E.K. (1980) Mechanism by which progesterone shortens the estrous cycle of the ewe. Biol. Reprod. 23, 1046-1053.

Pierson, R.A. \& Ginther, O.H. (1988) Ultrasonic imaging of the ovaries and uterus in cattle. Theriogenology 29, 21-37.

Rajamahendran, R. \& Taylor, C. (1990) Characterization of ovarian activity in postpartum dairy cows using ultrasound imaging and progesterone profiles. Anim. Reprod. Sci. 22, 171-180.

Rajamahendran, R. \& Walton, J.S. (1988) Follicular development and corpus luteum formation in postpartum dairy cattle. Jith Int. Cong. Anim. Repro. and Artif. Insem. 2, $60-62$.

Rajamahendran, R. \& Waiton, J.S. (1990) Effect of treatment with estradiol valerate on endocrine changes and ovarian follicle populations in dairy cows. Theriogenology 33, 441-452.

Rajamahendran, R., Lague, P.C. \& Baker, R.D. (1981) Serum hormone levels and occurrence of oestrus following use of an intravaginal device containing progesterone and oestradiol $17 \beta$ in heifers. Anim. Reprod. Sci. 3, 271-277.

Rajamahendran, R., Robinson, J., Desbottes, S. \& Walton, J.S. (1989) Temporal relationships among estrus, body temperature, milk yield, progesterone and luteinizing hormone levels, and ovulation in dairy cows. Theriogenology 31, 1173-1182. 
Rentfrow, L.R., Randel, R.D. \& Neuendorff, D.A. (1987) Effect of estrous synchronization with Syncro-Mate $B$ on serum luteinizing hormone, progesterone and conception in Brahman heifers. Theriogenology 28, 355-362.

Roberson, M.S., Wolfe, M.W., Stumpf, T.T., Kittok, R.J. \& Kinder, J.E. (1989) Luteinizing hormone secretion and corpus luteum function in cows receiving two levels of progesterone. Biol. Reprod. 41, 997-1003.

Savio, J.D., Keenan, L., Boland, M.P. \& Roche, J.F. (1988) Pattern of growth of dominant follicles during the oestrous cycle of heifers. J. Reprod. Fert. 83, $663-671$.

Schams, D., Schallenberger, E., Hoffman, B. \& Karg, H. (1977) The oestrous cycle of the cow; hormonal parameters and time relationships concerning oestrus, ovulation and electrical resistance of the vaginal mucus. Acta Endocr. (Copenh.) 86, 180-191.

Short, J.R.E., Bellow, R.A., Carr, J.B., Straigmiller, R.B. \& Randel, R.D. (1976) Induced or synchronized puberty in heifers. J. Anim. Sci. 43, 1254-1263.

Sirois, J. \& Fortune, J.E. (1988) Ovarian follicular dynamics during the estrous cycle in heifers monitored by real-time ultrasonography. Biol. Reprod. 39, $308-317$
Sirois, J., Hinshelwood, M.M. \& Fortune, J.E. (1989) Lengthening the estrous cycle with low levels of progesterone prolongs ovarian follicular dominance in heifers. Biol. Reprod. (Suppl. 1.) 40, 168.

Spitzer, J.C., Jones, D.L., Miksh, E.D. \& Wiltbank, J.N. (1978) Synchronization of estrus in beef cattle. III. Field trial in heifers using a norgestomet implant and injections of norgestomet and estradiol valerate. Theriogenology 10, 223-229.

Taylor, C. \& Rajamahendran, R. (1989) Ovarian and uterine characteristics of early pregnant and nonpregnant dairy cattle as seen by ultrasound imaging. Can. J. Anim. Sci. 69, 1134.

Vostermans, J.P.M. \& Walton, J.S. (1985) Effect of intermittent injections of gonadotropin releasing hormone and ovulation in dairy cows. Anim. Reprod. Sci. 8, 335-347.

Wiltbank, J.N. \& Gonzalez-Padilla, E. (1975) Synchronization and induction of estrus in heifers with a progestagen and estrogen. Ann. Biol. Anim. Biochem. Biophys. 15, 255-262.

Received 24 September 1990 